\title{
Impact of sex ratio and stocking density on the induced spawning of the Egyptian sole (Solea aegyptiaca Chabanaud, 1927).
}

\author{
Hamed H. E. Saleh ${ }^{1}$, Ragab A. Mohammed ${ }^{1}$, Ramadan M. Abou-Zied ${ }^{2}$, \\ Sobhy M. Allam² and Safaa S. A. Aljilany ${ }^{1}$ \\ 1- National Institute of Oceanography and Fisheries (NIOF), Egypt. \\ 2- Animal Production Department, Faculty of Agriculture, Fayoum University, Egypt. \\ *Corresponding author: E-mail: hhsaleh90@gmail.com
}

\section{ABSTRACT}

This study was conducted to evaluate the impact of sex ratio and stocking density on the induced spawning and reproductive performance of the Egyptian sole (Solea aegyptiaca) broodstock. Broodstock spawners were intermuscularly injected with Human Chorionic Gonadotropin Hormone (HCG) below the dorsal fine base; the dose was $7000 \mathrm{IU} / \mathrm{Kg}$ body weight of fish. In this study, three different broodstock sex ratios: 1:1, 1:2 and 2:1 (male $\delta$ : female + ) were tested. The highest fertilized eggs/ treatment and larvae/ treatment were observed in sex ratio $\left(10^{\lambda}: 2\right.$ + $)$. While, the highest fertilized eggs/ female, fertilized eggs/ g female, hatching rate and number of spawning were observed in sex ratio $(2 \delta: 1+$ ). Under the conditions tested in this study, larvae production of $S$. aegyptiaca was affected by different broodstock sex ratios and improved at a sex ratio $\left(1 \delta^{\top}: 2\right.$ + $)$. Also, four different broodstock stocking densities: $0.5,0.75,1,1.25 \mathrm{Kg} / \mathrm{m}^{3}$ were tested. The highest fertilized eggs/ treatment, fertilized eggs/ $\mathrm{g}$ female and larvae/ treatment were observed in stocking density $0.75 \mathrm{Kg} / \mathrm{m}^{3}$ followed the other stocking densities. The lowest fertilized eggs/ female and/ $\mathrm{g}$ female were observed in stocking density 1.25 $\mathrm{Kg} / \mathrm{m}^{3}$. Under the conditions tested in this study, larvae production of S. aegyptiaca was affected by different broodstock stocking densities and the best stocking density was $0.75 \mathrm{Kg} / \mathrm{m}^{3}$. Also, results demonstrated superiority of artificial spawning compared to natural one. From the results of this study, it is recommended to use artificial spawning in $S$. aegyptiaca with sex ratio $\left(1 \delta^{\lambda}: 2\right.$ \% $)$ and stocking density $(0.75$ $\left.\mathrm{Kg} / \mathrm{m}^{3}\right)$.

Keywords: Solea aegyptiaca, induced spawning, reproductive performance, sex ratio, stocking density

\section{INTRODUCTION}

The common sole Solea solea and the Egyptian sole S. aegyptiaca (Family: Soleidae) are the most important sole species that occurs in the Egyptian waters. They tend to occupy shallow, sandy and sandy/muddy habitats as well as the shallow lagoons. The common sole is highly appreciated fish by the Egyptians especially in the coastal communities because of its high quality flesh and is one of the commercially important fish in Egypt providing up to 90 million LE annually. Despite its worldwide importance, little work has been dedicated on its reproductive biology (Mehanna, 2014). The Egyptian sole (Solea aegyptiaca) is the most common species of soles that contributed about $6.5 \%$ of the total catch of trawl fishery, forming about $13 \%$ of the gross revenue of the trawling (Mehanna, 2007). Kariman (2009) recorded that catch composition of sole species during summer and winter seasons in Lake Qarun were more than 50 and 35\%, respectively. In Egypt, the information about the reproductive biology of this species is very scarce (Salman, 2014). 
El-Husseiny (2001) reported that the Gonado-somatic index (GSI) of female of S. aegyptiaca, in Lake Quarun, increased progressively to reach its maximum value in January, while the minimum value was recorded in July, while Ahmed et al. (2010) found that the monthly changes in GSI of males and females S. aegyptiaca showed a definite breeding season which extends from January to June. Both sexes reached the highest values of GSI in January, while the minimum was in June and August for females and males respectively. Salman (2014) confirmed that the common sole in Bardawil lagoon is a winter spawner and spawned once a year. Mehanna (2014) confirmed that the common sole, S. solea, in Bardawil lagoon is a winter spawner and spawn once a year and its spawning period occurs between October and April with a peak activity during December. In the wild, Solea vulgaris are reproductively active throughout the period from December to late March (Assem, 1995).

Herrera et al. (2008), studied reproduction and breeding of the wedge sole in captivity and indicated that the breeders adapt easily to captivity, and they can spawn in less than one year in captivity. In Egypt, common sole, S. solea, was successfully hatched for the first time in 1986 and juveniles were obtained and maintained in healthy conditions (Zaki and Hamza 1986; Assem et al., 2012). Eisawy and ElBolock (1975) indicated that Solea aegyptiaca spawned and propagated successfully in Lake Qarun and it makes up about $36 \%$ of the total catch of lake. Artificial spawning of Solea solea was recommended by Zaki and Hamza (1988); Assem (1995); Agulleiro et al. (2006); Assem et al. (2012). Assem (1995) studied the reproductive biology of both Solea aegyptiaca and Solea vulgaris. Furthermore, he studied induction of spawning by using hormonal treatments, and then studied embryonic and larval developmental stages.

Hormonal induction of spawning is usually carried out with fish which normally do not spawn spontaneously in captivity. For fish species which spawn naturally under confinement, hormonal manipulation is done to synchronize spawnings of several females for mass fry production. Human chorionic gonadotropin (HCG) has been used successfully to induce ovulation and spawning in a number of fish species as reviewed by Donaldson and Hunter (1983). It is used either alone or in combination with other hormones. One advantage in using HCG over other hormones is that its potency can be standardized in international units and results can be compared among users (Lee et al., 1988). Assem (1995) reported that, in artificial spawning of Solea solea, the total number of spawned egg varied between $1.3 \times 10^{6}$ egg per $\mathrm{Kg}$ minimally and $2.1 \times 10^{6}$ egg per $\mathrm{Kg}$ maximally at water temperature $17 \pm 2.2^{\circ} \mathrm{C}$ and salinity $34 \pm 1 \%$. Herrera et al. (2008), indicated that for Wedge sole (Dicologoglossa cuneata) a relative fecundity reached $1.06-2.33 \times 10^{6} \mathrm{egg} / \mathrm{Kg}$ per spawning season, gametes are released in a wide temperature range; $10-21{ }^{\circ} \mathrm{C}$. Assem et al. (2012) reported that, in artificial spawning of Solea vulgaris, the total number of fertile ovae varied between 87,000 to 120,000 eggs/ spawn which represent $430 \pm 108$ eggs/g female. The percent of fertilization varied between 80 and $93 \%$ in water temperature of $17 \pm 2$ and salinity $34 \pm 1 \%$.

The aim of the present study was to evaluate the impact of sex ratio and stocking density on the induced spawning and reproductive performance of the Egyptian sole (Solea aegyptiaca) broodstock. 


\section{MATERIALS AND METHODS}

\section{Broodstock- rearing conditions}

Egyptian sole, Solea aegyptiaca broodstock (31-83 g/fish, body weight), used in the spawning trials were obtained from Lake Qaroun, El- Fayoum Governorate. They were obtained during the beginning of December 2014 and maintained at National Institute of Oceanography and Fisheries (NIOF), Shakshouk Fish Research Station, El- Fayoum Governorate and acclimated to laboratory conditions for 14 days in rectangular fiberglass tanks $\left(1.5 \mathrm{~m}^{3}\right.$ capacity $)$ then injected by human chorionic gonadotropin (HCG) hormone and randomly distributed into circular fiberglass tanks $\left(1 \mathrm{~m}^{3}\right.$ capacity). All tanks were provided with continuous aeration. The bottom of each tank was covered by a sand layer about $(5-10 \mathrm{~cm})$ for shelter. Fish were held under natural photoperiod condition throughout the spawning trials. Water temperature, dissolved oxygen, $\mathrm{pH}$, total ammonia, un-ionized ammonia, nitrite and nitrate were measured in all trials. The water used in the all trials was obtained from Lake Qaroun. No feed were offered for fish, but zooplankton in water in all trials were count during experimental period (Table 1). The average water quality criteria in all trials are presented in Table (2). About $25 \%$ of water tanks were changed twice every day. The trials began 14/12/2014 and ended 14/4/2015, (120 days).

Table 1: Zooplankton species and count during experimental period (No. of zooplankton/ liter) (Mean \pm S.E).

\begin{tabular}{|l|c|c|c|}
\hline \multirow{2}{*}{\multicolumn{1}{c|}{ Species }} & Natural & \multicolumn{2}{c|}{ Induced spawning } \\
\cline { 3 - 4 } & spawning & Sex ratio & Stocking density \\
\hline Brchionus plicatilis & $2 \pm 1$ & $1.5 \pm 0.5$ & $1.5 \pm 0.5$ \\
\hline Nauplis larvae & $110 \pm 40$ & $87.5 \pm 37.5$ & $16 \pm 3$ \\
\hline Fevelli sp. & $19 \pm 14$ & $18 \pm 16$ & $3 \pm 2$ \\
\hline Cirripedia larvae & $1.5 \pm 0.5$ & $1.5 \pm 0.5$ & $1.5 \pm 0.5$ \\
\hline Annelida larvae & $1.5 \pm 0.5$ & $1.5 \pm 0.5$ & $2 \pm 1$ \\
\hline Mesochra heldti & $1.5 \pm 0.5$ & $2 \pm 1$ & $2 \pm 1$ \\
\hline Total count zooplankton & $135.5 \pm 56.5$ & $96.5 \pm 37.5$ & $26 \pm 2$ \\
\hline
\end{tabular}

Table 2: Average values of water quality parameters during experimental periods (Mean \pm S.E).

\begin{tabular}{|l|c|c|c|}
\hline \multirow{2}{*}{ Parameters } & Natural & \multicolumn{2}{c|}{ Induced spawning } \\
\cline { 3 - 4 } & spawning & Sex ratio & Stocking density \\
\hline Temperature, ${ }^{\circ} \mathrm{C}$ & $16 \pm 3$ & $15.5 \pm 2.5$ & $16 \pm 3$ \\
\hline $\mathrm{pH}$ & $8.16 \pm 0.12$ & $8.22 \pm 0.11$ & $8.17 \pm 0.11$ \\
\hline Salinity, \%o & $32.5 \pm 1.5$ & $32.5 \pm 1.5$ & $32.5 \pm 1.5$ \\
\hline Dissolved oxygen, mg/l & $8.3 \pm 0.3$ & $8.3 \pm 0.3$ & $8.3 \pm 0.3$ \\
\hline Total ammonia, mg/l & $0.38 \pm 0.02$ & $0.39 \pm 0.01$ & $0.46 \pm 0.07$ \\
\hline Un-ionized ammonia, mg/l & $0.015 \pm 0.001$ & $0.015 \pm 0.001$ & $0.018 \pm 0.003$ \\
\hline Nitrite, $\mathrm{mg} / \mathrm{l}$ & $0.125 \pm 0.001$ & $0.125 \pm 0.001$ & $0.351 \pm 0.225$ \\
\hline Nitrate, $\mathrm{mg} / \mathrm{l}$ & $0.451 \pm 0.029$ & $0.466 \pm 0.046$ & $0.857 \pm 0.411$ \\
\hline
\end{tabular}

\section{Induce spawning}

Solea aegyptiaca spawners were intermuscularly injected with HCG, the commercial name Pregnyl ${ }^{\mathbb{R}}$ (Pregnyl ${ }^{\mathbb{R}}$ N.V. Organon Oss the Netherlands) below the dorsal fine base. The dose was $7000 \mathrm{IU} / \mathrm{Kg}$ body weight of fish. The females were ranged from 35 to $83 \mathrm{~g} /$ fish in body weight and 15.7 to $20.5 \mathrm{~cm} /$ fish in body length, while the males were ranged from 31 to $58 \mathrm{~g} /$ fish in body weight and 15.4 to 18.6 $\mathrm{cm} /$ fish in body length. 


\section{Experimental design}

The first experiment was conducted to investigate the effect of different sex ratio (1:1, 1:2 and 2:1, male $\delta^{\lambda}$ : female + ) on induced spawning of Solea aegyptiaca with stocking density of approximately $0.5 \mathrm{Kg} / \mathrm{m}^{3}$. The second experiment was conducted to investigate the effect of different stocking density $(0.5,0.75,1$ and 1.25 $\mathrm{Kg} / \mathrm{m}^{3}$ ) with sex ratio (1 Female: 1 Male) on induced spawning of Solea aegyptiaca. The third experiment to evaluate and compare between induced spawning and natural spawning.

\section{Water quality analysis}

Water temperature and $\mathrm{pH}$ were measured daily by Combined meter $(\mathrm{pH} / \mathrm{EC} /$ TDS/ temperature, Mi 805). Salinity was measured daily by Refractometer (VITAL Sine SR-6, China). Dissolved oxygen (DO) concentration was determined titrimetrically according to the modified Winkler, full-bottle technique (Method 360.2; EPA, 1983). Water ammonia, nitrite and nitrate were determined by using Spectrophotometer model (LKB Bichrom UV visible spectrophotometer) according to the method described by APHA (1992). To determine un-ionized ammonia concentration, multiply total ammonia concentration by the percentage which is closest to the observed temperature and $\mathrm{pH}$ of the water sample (Swann, 1997).

\section{Enumeration and identification of zooplankton in water}

Zooplankton samples were collected using zooplankton net. The samples were fixed immediately using formaldehyde solution (4-7\%), two $\mathrm{ml}$ of Rose Bengal stain $(0.5 \%)$ was added after fixation. The samples were examined under a binocular research microscope. The organisms were identified and counted on the counting try with magnification varying from $100 \mathrm{X}$ to $400 \mathrm{X}$. Planktonic organisms were identified, classified and described according to description and keys constructed by Ruttner-Kolisko (1974); Campbell (1982); Abdel-Malek et al. (1993); Parveen and Mola (2013).

\section{Statistical analysis}

The data were analyzed by one-way ANOVA and significant differences were determined by Duncan Waller Multiple Range Test at 5\% level using SPSS Statistical Package Program (SPSS, 2008) 17, released version.

\section{RESULTS}

During experimental period from $14 / 12 / 2014$ to $14 / 4 / 2015$, about $100 \%$ spawning success rate for Egyptian sole broodstock injected, using Human Chorionic Gonadotropin Hormone (HCG). After $48 \mathrm{~h}$ from the resolving injection the female spawns, the mean total number of fertilized eggs varied between 2200 minimally and 6280 maximally per female and hatching rate varied between $90 \%$ minimally and 95\% maximally, according to treatments differences (sex ratio and stocking density). The Egyptian sole fish always spawn at night; fish spawn pelagic eggs, which are fertilized externally and float individually near the water surface. The ripe eggs of Solea aegyptiaca appeared rounded, colorless and transparent, with a diameter of about $0.85 \mathrm{~mm}$. The surface of the fertilized egg shell is smooth, the fertilized egg appeared rounded and was about $0.92 \mathrm{~mm}$ in diameter. The results showed that hatching of Solea aegyptiaca eggs occured after $48 \pm 3 \mathrm{~h}$ from fertilization at temperature $17-19{ }^{\circ} \mathrm{C}$, while occured after $60-72 \mathrm{~h}$ from fertilization at temperature 14-16 ${ }^{\circ} \mathrm{C}$. Newly hatched larva was about $1.42 \mathrm{~mm}$ in length. In the present study, there were some unfertilized eggs were recorded in all treatments. 


\section{The first experiment: Effect of sex ratio on reproductive performance}

Reproductive performance parameters of the Egyptian sole broodstock under effect of sex ratio are shown in Tables ( 3 and 4). The results cleared that the sex ratio had significant effects $(\mathrm{P} \leq 0.05)$ on the reproductive performance parameters such as number of fertilized eggs/ treatment, number of fertilized eggs/ female, number of fertilized eggs/ g female, number of larvae/ treatment and hatching rate (\%). While, number of spawning and survival rate (\%) showed insignificant differences between treatments.

Table 3: Effect of sex ratio on induced spawning of the Egyptian sole, Solea aegyptiaca.

\begin{tabular}{|c|c|c|c|c|}
\hline \multirow[b]{2}{*}{ Items } & \multicolumn{3}{|c|}{ Sex ratio (male $\delta^{\lambda}$ : female $Q$ ) } & \multirow[b]{2}{*}{ SED* } \\
\hline & $\mathbf{1} \bigcirc^{\wedge} \mathbf{1} \bigcirc$ & $\mathbf{1} \delta^{\wedge} \mathbf{2} \bigcirc$ & $\mathbf{2} \bigcirc^{\wedge} \mathbf{1}+$ & \\
\hline No. of fertilized eggs/ treatment & $30566^{\mathrm{b}}$ & $43986^{\mathrm{a}}$ & $30986^{\mathrm{b}}$ & 341.955 \\
\hline No. of fertilized eggs/ female & $5094.33^{b}$ & $4398.60^{c}$ & $6197.20^{\mathrm{a}}$ & 52.440 \\
\hline No. of fertilized eggs/g female & $94.34^{\mathrm{c}}$ & $112.21^{b}$ & $132.99^{\mathrm{a}}$ & 1.126 \\
\hline No. of larvae/ treatment & $28278^{b}$ & $39629^{\mathrm{a}}$ & $29457^{b}$ & 819.174 \\
\hline Hatching rate, $\%^{1}$ & $92.51^{\mathrm{ab}}$ & $90.09^{b}$ & $95.06^{\mathrm{a}}$ & 1.439 \\
\hline No. of spawning & 5 & 5 & 7 & - \\
\hline Survival rate, $\%{ }^{2}$ & 100 & 100 & 100 & - \\
\hline
\end{tabular}

- $(a, b, c)$ Average in the same row having different superscripts are differ significantly $(\mathrm{P} \leq 0.05)$.

SED is the standard error of difference

1 , Hatching rate, $\%=($ Number of larvae/ Number of fertilized eggs per treatment $) \times 100$.

2 , Survival rate, $\%=($ Number of fish at end $/$ Number of fish at start $) \times 100$.

The results also showed that, the highest fertilized eggs/ treatment (43986 egg) and larvae/ treatment (39629 larvae) were observed in sex ratio (1 male $\delta^{\top}: 2$ female ㅇ), thereafter, sex ratios $\left(2 \delta^{\Uparrow}: 1+\right.$ ) $\left(30986 \mathrm{egg}, 29457\right.$ larvae) and $\left(1 \delta^{\lambda}: 1\right.$ ) $)(30566 \mathrm{egg}$, 28278 larvae). While, the highest fertilized eggs/ female (6197.20 egg) were observed in sex ratio $\left(2 \hat{O}^{\lambda}: 1\right.$ ) $)$, followed sex ratio $\left(1 \delta^{\lambda}: 1+\right.$ ) $(5094.33 \mathrm{egg})$ then sex ratio $\left(1 \delta^{\lambda}: 2\right.$ ) $)$ (4398.60). The highest fertilized eggs/ g female (132.99 egg) were observed in sex ratio $\left(2 \delta^{\lambda}: 1\right.$ ) $)$, followed sex ratio $\left(1 \delta^{\top}: 2\right.$ ) $)(112.21 \mathrm{egg})$ then sex ratio $\left(1 \hat{\delta}: 1\right.$ ) (94.34). The highest hatching rate was observed in sex ratio $\left(2 \delta^{\lambda}: 1\right.$ ) $(95.06 \%)$, followed by sex ratio $\left(1 \delta^{\lambda}: 1 \%\right)$ then $\left(1 \delta^{\lambda}: 2\right.$ ) 92.51 and $90.09 \%$, respectively. Numbers of spawning values were relatively highest with sex ratio $\left(2 \delta^{\lambda}: 1+\right)$. These results indicated that the best sex ratio was recorded with $\left(1 \delta^{\lambda}: 2 \bigcirc\right)$ at obtained fertilized eggs/ treatment and larvae/ treatment. While, the best sex ratio was recorded with $\left(2 \delta^{\lambda}: 1\right.$ ) $)$ on fertilized eggs/ female, fertilized eggs/g female, hatching rate and number of spawning under experimental conditions.

Table 4: Effect of sex ratio on induced spawning of Solea aegyptiaca (hormone dose, date of injection and date of ovulation).

\begin{tabular}{|c|c|c|c|}
\hline \multirow[t]{2}{*}{ Items } & \multicolumn{3}{|c|}{ Sex ratio (male ${ }^{\lambda}$ : female ${ }^{\prime}$ ) } \\
\hline & $\mathbf{1} 0^{\Uparrow} \mathbf{1} 9$ & $\mathbf{1})^{\wedge} \mathbf{2} \bigcirc$ & $\mathbf{2} \overbrace{}^{\lambda} \mathbf{1} 9$ \\
\hline Hormone dose & \multicolumn{3}{|c|}{$7000 \mathrm{IU} / \mathrm{kg}$ fish } \\
\hline Date of injection & \multicolumn{3}{|c|}{$14 / 12 / 2014$} \\
\hline \multicolumn{4}{|c|}{ Date of ovulation } \\
\hline The first & $16 / 12 / 2014$ & $16 / 12 / 2014$ & $16 / 12 / 2014$ \\
\hline The second & $25 / 12 / 2014$ & $25 / 12 / 2014$ & $25 / 12 / 2014$ \\
\hline The third & $3 / 1 / 2015$ & $3 / 1 / 2015$ & $3 / 1 / 2015$ \\
\hline The fourth & $17 / 1 / 2015$ & $18 / 1 / 2015$ & $17 / 1 / 2015$ \\
\hline The fifth & $29 / 1 / 2015$ & $29 / 1 / 2015$ & $28 / 1 / 2015$ \\
\hline The sixth & -- & -- & $8 / 2 / 2015$ \\
\hline The seventh & -- & -- & $12 / 3 / 2015$ \\
\hline
\end{tabular}




\section{The second experiment: Effect of stocking density on reproductive performance}

Reproductive performance parameters of the Egyptian sole broodstock under effect of stocking density are shown in Tables (5 and 6). The results cleared that the stocking density had significant effects $(\mathrm{P} \leq 0.05)$ on the reproductive performance parameters such as number of fertilized eggs/ treatment, number of fertilized eggs/ female, number of fertilized eggs/g female and number of larvae/ treatment. While, hatching rate $(\%)$, number of spawning and survival rate $(\%)$ had insignificant differences among treatments.

Table 5: Effect of stocking density on induced spawning of the Egyptian sole, Solea aegyptiaca.

\begin{tabular}{|c|c|c|c|c|c|}
\hline \multirow[t]{2}{*}{ Items } & \multicolumn{4}{|c|}{ Stocking density $\left(\mathrm{Kg} / \mathrm{m}^{3}\right)$} & \multirow[t]{2}{*}{ SED* } \\
\hline & 0.5 & 0.75 & 1 & 1.25 & \\
\hline No. of fertilized eggs/ treat. & $31386^{b}$ & $58840^{\mathrm{a}}$ & $30636^{\mathrm{b}}$ & $30986^{b}$ & 433.013 \\
\hline No. of fertilized eggs/ female & $6277.2^{\mathrm{a}}$ & $5884^{\mathrm{b}}$ & $2785.09^{\mathrm{c}}$ & $2213.29^{d}$ & 52.179 \\
\hline No. of fertilized eggs/g female & $98.70^{\mathrm{b}}$ & $129.32^{\mathrm{a}}$ & $53.00^{\mathrm{c}}$ & $43.22^{\mathrm{d}}$ & 0.997 \\
\hline No. of larvae/ treat. & $28742^{b}$ & $54826^{\mathrm{a}}$ & $28111^{b}$ & $28566^{\mathrm{b}}$ & 983.589 \\
\hline Hatching rate, $\%^{1}$ & 91.57 & 93.17 & 91.75 & 92.19 & 1.493 \\
\hline No. of spawning & 5 & 7 & 7 & 5 & - \\
\hline Survival rate, $\%{ }^{2}$ & 100 & 100 & 100 & 100 & - \\
\hline
\end{tabular}

- $(a, b, c)$ Average in the same row having different superscripts are differ significantly $(\mathrm{P} \leq 0.05)$.

* SED is the standard error of difference

1 , Hatching rate, $\%=($ Number of larvae/ Number of fertilized eggs per treatment $) \times 100$.

2 , Survival rate, $\%=($ Number of fish at end $/$ Number of fish at start $) \times 100$.

Fertilized eggs/ treatment values were highest with stocking density $(0.75$ $\mathrm{Kg} / \mathrm{m}^{3}$ ) followed the other stocking densities. Fertilized eggs/ female values were highest with stocking density $\left(0.5 \mathrm{Kg} / \mathrm{m}^{3}\right)$, while the lowest value with stocking density $\left(1.25 \mathrm{Kg} / \mathrm{m}^{3}\right)$. Fertilized eggs/ $\mathrm{g}$ female values were highest with stocking density $\left(0.75 \mathrm{Kg} / \mathrm{m}^{3}\right)$, while the lowest value was with stocking density $\left(1.25 \mathrm{Kg} / \mathrm{m}^{3}\right)$. Number of larvae/ treatment values were highest with stocking density $\left(0.75 \mathrm{Kg} / \mathrm{m}^{3}\right)$ followed the other stocking densities. Hatching rates were relatively highest with stocking density $\left(0.75 \mathrm{Kg} / \mathrm{m}^{3}\right)$ followed the other stocking densities. Number of spawning values were relatively highest under stocking density $\left(0.75\right.$ and $\left.1 \mathrm{Kg} / \mathrm{m}^{3}\right)$ followed stocking density $\left(0.5\right.$ and $\left.1.25 \mathrm{Kg} / \mathrm{m}^{3}\right)$. These results indicated that the best stocking density is $\left(0.75 \mathrm{Kg} / \mathrm{m}^{3}\right)$ on reproductive performance parameters for the Egyptian sole broodstock under experimental conditions.

Table 6: Effect of stocking density on induced spawning of Solea aegyptiaca (hormone dose, date of injection and date of ovulation).

\begin{tabular}{|l|c|c|c|c|}
\hline \multirow{2}{*}{ Items } & \multicolumn{4}{|c|}{ Stocking density ( Kg/ $\mathbf{~ m}^{\mathbf{3}}$ ) } \\
\cline { 2 - 5 } & $\mathbf{0 . 5}$ & $\mathbf{0 . 7 5}$ & $\mathbf{1}$ & $\mathbf{1 . 2 5}$ \\
\hline Hormone dose & \multicolumn{4}{|c|}{ Date of ovulation IU/kg fish } \\
\hline Date of injection & \multicolumn{4}{|c|}{$14 / 2014$} \\
\hline \multicolumn{5}{|c|}{} \\
\hline The first & $16 / 12 / 2014$ & $16 / 12 / 2014$ & $16 / 12 / 2014$ & $16 / 12 / 2014$ \\
\hline The second & $25 / 12 / 2014$ & $14 / 12 / 2014$ & $25 / 12 / 2014$ & $25 / 12 / 2014$ \\
\hline The third & $3 / 1 / 2015$ & $3 / 1 / 2015$ & $3 / 1 / 2015$ & $3 / 1 / 2015$ \\
\hline The fourth & $17 / 1 / 2015$ & $17 / 1 / 2015$ & $18 / 1 / 2015$ & $17 / 1 / 2015$ \\
\hline The fifth & $28 / 1 / 2015$ & $28 / 1 / 2015$ & $30 / 1 / 2015$ & $30 / 1 / 2015$ \\
\hline The sixth & -- & $8 / 2 / 2015$ & $10 / 2 / 2015$ & -- \\
\hline The seventh & -- & $3 / 3 / 2015$ & $4 / 3 / 2015$ & -- \\
\hline
\end{tabular}




\section{The third experiment: Comparative study between induced and natural spawning on reproductive performance}

The results (Tables 7 and 8) showed that there are significant differences $(\mathrm{P} \leq 0.05)$ between induced and natural spawning in all reproductive performance parameters, except the number of spawning and survival rate. Reproductive performance parameters values were highest with induced spawning except the number of spawning compared with natural spawning. These results indicated that the induced spawning was better than natural spawning for the Egyptian sole broodstock under experimental conditions.

Table 7: Comparative study between induced and natural spawning of the Egyptian sole, Solea aegyptiaca.

\begin{tabular}{|l|c|c|c|}
\hline \multicolumn{1}{|c|}{ Items } & $\begin{array}{c}\text { Induced } \\
\text { spawning }\end{array}$ & $\begin{array}{c}\text { Natural } \\
\text { spawning }\end{array}$ & SED* \\
\hline No. of fertilized eggs/ treatment & $30566^{\mathrm{a}}$ & $21460^{\mathrm{b}}$ & 252.389 \\
\hline No. of fertilized eggs/ female & $5094.33^{\mathrm{a}}$ & $3065.71^{\mathrm{b}}$ & 40.311 \\
\hline No. of fertilized eggs/g female & $94.34^{\mathrm{a}}$ & $68.35^{\mathrm{b}}$ & 0.785 \\
\hline No. of larvae/ treatment & $28278^{\mathrm{a}}$ & $19032^{\mathrm{b}}$ & 665.954 \\
\hline Hatching rate, \% & $92.51^{\mathrm{a}}$ & $88.68^{\mathrm{b}}$ & 1.662 \\
\hline No. of spawning & 5 & 9 & - \\
\hline Survival rate, \% & 100 & 96.43 & 3.570 \\
\hline
\end{tabular}

- $(\mathrm{a}, \mathrm{b}, \mathrm{c})$ Average in the same row having different superscripts are differ significantly $(\mathrm{P} \leq 0.05)$.

* SED is the standard error of difference

Table 8: Comparative study between induced and natural spawning of Solea aegyptiaca (hormone dose, date of injection and date of ovulation).

\begin{tabular}{|l|c|c|}
\hline \multicolumn{1}{|c|}{ Items } & Induced spawning & Natural spawning \\
\hline Hormone dose & $7000 \mathrm{IU} / \mathrm{kg}$ fish & - - \\
\hline Date of injection & $14 / 12 / 2014$ & - \\
\hline \multicolumn{3}{|c|}{ Date of ovulation } \\
\hline The first & $16 / 12 / 2014$ & $20 / 12 / 2014$ \\
\hline The second & $25 / 12 / 2014$ & $17 / 1 / 2015$ \\
\hline The third & $3 / 1 / 2015$ & $28 / 1 / 2015$ \\
\hline The fourth & $17 / 1 / 2015$ & $8 / 2 / 2015$ \\
\hline The fifth & $29 / 1 / 2015$ & $23 / 2 / 2015$ \\
\hline The sixth & -- & $5 / 3 / 2015$ \\
\hline The seventh & -- & $12 / 3 / 2015$ \\
\hline The eighth & -- & $21 / 3 / 2015$ \\
\hline The nineth & -- & \\
\hline
\end{tabular}

\section{DISCUSSION}

Broodstock productivity clearly represents the most significant constraint on commercial fish production. Increased knowledge of the factors regulating broodstock productivity is therefore of great importance to the further development of Solea aegyptiaca culture. Hormonal induction of ovulation for Solea aegyptiaca was successful with human chorionic gonadotropin hormone (HCG). In the present study, artificial spawning of Solea aegyptiaca were achieved using HCG (total dose 7000 $\mathrm{IU} / \mathrm{Kg}$ fish body weight).

In other studies, Assem et al. (2012) showed that, artificial spawning of Solea vulgaris were achieved using carp pituitary extract (CPE) from 40-70 $\mu \mathrm{g} /$ fish (equal to $200 \mu \mathrm{g} / \mathrm{Kg}$ fish) or HCG from 2300 to $3000 \mathrm{IU} /$ fish (equal to $10000 \mathrm{IU} / \mathrm{Kg}$ fish) as a priming dose, followed by luteinizing and releasing hormone analogue (LHRHa) from $52-60 \mu \mathrm{g} /$ fish (equal to $200 \mu \mathrm{g} / \mathrm{Kg}$ fish) in the resolving dose. Berlinsky et al. 
(1997) induced the ovulation of $P$. dentatus with HCG (total dose for ovulation equal to $500 \mathrm{IU} / \mathrm{Kg}$ ) and CPE (total dose for ovulation equal to $16 \mathrm{mg} / \mathrm{Kg}$ ). Ovulation of P. tropicus was obtained with HCG $2000 \mathrm{IU} / \mathrm{Kg}$ (Rosas et al., 1999). Guzman et al. (2009) compared the efficiency of two sustained-release delivery systems loaded with GnRHa and a single GnRHa injection on the stimulation of oocyte maturation, sex steroid hormone secretion and spawning of Senegalese sole (Solea senegalensis). Agulleiro et al. (2006) studied induction of spawning of captive-reared Senegal sole (Solea senegalensis) using different administration methods for gonadotropinreleasing hormone agonist and concluded that: female injected with a dose of $5 \mu \mathrm{g}$ $\mathrm{GnRHa} / \mathrm{kg}$ three times a week, or treated with a single GnRHa loaded implant (50 $\mu \mathrm{g} / \mathrm{kg}$ ) showed multiple ovulations and spawns within a period of approximatiple 30 days. Mylonas and Zohar (2001) listed nine flatfish species where ovulation and/or spawning was induced using different GnRHa delivery system ranging from 30 to $1000 \mu \mathrm{g} / \mathrm{kg}$. From these finding, it is concluded that hormonal induction of ovulation for sole fish was successful with HCG, CPE, LHRHa and GnRHa.

In the present study, Solea aegyptiaca fish always spawn at night; fish spawn pelagic eggs, which are fertilized externally and float individually near the water surface. The ripe eggs of Solea aegyptiaca appeared rounded, colorless and transparent. The surface of the fertilized egg shell is smooth, the fertilized egg appeared rounded. Many authors were in agreement with this description of the present study Assem et al. (2012) for Solea vulgaris, Zaki and Hamza (1988); Assem (1995); Baynes and Howell (1996) for Solea solea. In this study, the ripe and fertile eggs of Solea aegyptiaca was about 0.85 and $0.92 \mathrm{~mm}$ in diameter, respectively and newly hatched larvae were about $1.42 \mathrm{~mm}$ in length. On the other hand, Assem et al. (2012) recorded that, the ripe and fertile eggs of Solea vulgaris was about 1.04 and $1.2 \pm 0.01 \mathrm{~mm}$ in diameter, respectively and newly hatched larvae was about 1.8 $\mathrm{mm}$ in length. Also, Yufera et al. (1999) recorded that, S. senegalensis spawned eggs of about $1 \mathrm{~mm}$ diameter. In addition, Herrera et al. (2008) mention that, the newly hatched wedge sole larvae were $2.34 \mathrm{~mm}$ in length. Moreover, Jimenez et al. (2001) reported that, the newly hatched wedge sole larvae total length in wild is 1.57 $\mathrm{mm}$. This value is smaller to that recorded in captivity $(2.39 \mathrm{~mm})$. This fact may be related to the large size of the captive breeders, as they were bigger than those found in the wild (Assem et al., 2012).

In the present study, hatching of Solea aegyptiaca eggs occured after $48 \pm 3 \mathrm{~h}$ from fertilization at temperature $17-19{ }^{\circ} \mathrm{C}$, while occured after $60-72 \mathrm{~h}$ from fertilization at temperature $14-16^{\circ} \mathrm{C}$. These results agreed with the results of Zaki et al. (1998) who reported that, the incubation period of eggs of Solea aegyptiaca at a temperature ranged from $16-18{ }^{\circ} \mathrm{C}$ is $48 \pm 6 \mathrm{~h}$. Also, Herrera et al. (2008) reported that, incubation lasted for $36-48 \mathrm{~h}$ for wedge sole at $19{ }^{\circ} \mathrm{C}$. Similarly, Salivatori et al. (1985) reported that hatching of Solea eggs occured after 45-46 h at temperature 16$18{ }^{\circ} \mathrm{C}$. Also, Zaki and Hamza (1986) incubated Solea solea eggs at temperature ranged between $11-17^{\circ} \mathrm{C}$ and hatched within 72-96 h. On the contrary, Assem et al. (2012) recorded that, Solea vulgaris eggs hatched after $38 \pm 2 \mathrm{~h}$ from fertilization at temperature of about $17 \pm 2{ }^{\circ} \mathrm{C}$. Also, Yufera et al. (1999) recorded that, S. senegalensis eggs hatched after $38 \mathrm{~h}$ from fertilization at temperature of about 19.5 ${ }^{\circ} \mathrm{C}$. In addition, Bedoui (1995) reported that hatching of Solea senegalensis eggs occured after $42 \mathrm{~h}$ at temperature $19{ }^{\circ} \mathrm{C}$. Moreover, Ramos (1986) showed that egg incubated at $20 \pm 1{ }^{\circ} \mathrm{C}$ and hatching occurred after 40-44 h. Also, Zaki and Hamza (1988) stated that incubation of Solea solea eggs varied from 3-4 days at $11-14^{\circ} \mathrm{C}$. Devauchelle et al. (1987) recorded that, Solea solea eggs hatched after 120 to $130 \mathrm{~h}$ 
from fertilization at temperature $13{ }^{\circ} \mathrm{C}$. From these finding, it is concluded that incubation period varied for the same species with variation of water temperature. Also, there is difference in hatching period with other species of fish.

In the present study, the percent of hatching rate varied between 90 and $95 \%$ at water temperature of $13-19{ }^{\circ} \mathrm{C}$ and salinity $31-34 \%$. Similar to our results, SalasLeiton et al. (2012) reported that, percent of hatching for Solea senegalensis is ranging between 80.7 and $95.7 \%$ at water temperature of $20{ }^{\circ} \mathrm{C}$ and salinity $18-33 \%$. Also, Assem et al. (2012) noticed that, percent of hatching for Solea vulgaris is ranging between 89 and $90 \%$ at water temperature of $17 \pm 2{ }^{\circ} \mathrm{C}$ and salinity $34 \pm 1 \%$. In contrast, Blanco-Vives et al. (2010) reported that, percent of hatching for $S$. senegalensis was $78.1 \%$ at water temperature of $16-19{ }^{\circ} \mathrm{C}$. Also, Dinis et al. (1999) mentioned that, percent of hatching for $S$. senegalensis was $72.1 \pm 26.5 \%$. Moreover, a hatching rate of the wedge sole (58.3- 85.2\%) were recorded by Herrera et al. (2008). As well as described by Anguis and Canavate (2005) for Senegal sole (55.4-70.9\%) and other cultured flatfish species as halibut (14-51\%) by Mazorra et al. (2003). In this study, the high hatching rate is possibly due to the selection broodstock (Fish were healthy, free from parasites) and/or to the quality of the used hormone.

\section{Effect of sex ratio}

Reproductive success in many fish species has been shown to be influenced by, among other factors, the broodstock, sex ratio, stocking density, age, size, nutrition and feeding regime (Ridha and Cruz, 1989; Smith et al., 1991; Salama, 1996; Izquierdo et al., 2001; Chong et al., 2004; Tahoun, 2007; Hammouda et al., 2008; Ibrahim et al., 2008).

Most studies on spawning of sole fish were used sex ratio at a rate of 1:1 male: female (Assem et al., 2012 for Solea vulgaris), (Blanco-Vives et al., 2010 for Solea senegalensis), (Blonk et al., 2009 for Solea solea) and sex ratio 1:1-1:1.2 male: female for Solea senegalensis by Guzman et al. (2009). While Cardinaletti et al. (2009) found that, the sex ratio was 1.2:1 male: female during spawning trial for Solea solea. Imsland et al. (2003) recorded that, the environmental conditions used for Solea solea and $S$. senegalensis broodfish we find in published studies: sex ratio of 0.5-3 males to each female. In flatfish species such as flounder (Paralichthys orbignyanus) sex ratio used for stocking was 1:0.7 that is ten females: seven males (Bambill et al., 2006). Some authors have recommended a sex ratio of 1-2 males: 1 female for Paralichthys orbignyanus reproduction, although the optimal ratio has not been determined yet (Kumagai 1999; Smith et al. 1999; Watanabe and Carroll 2001). In a study conducted on Solea solea in Bardawil lagoon, Mehanna (2014) found that, the sex ratio was 1:2.11 males to females during spawning season. In the an other study conducted on Solea aegyptiaca in Port said, Egypt, Mediterranean sea, Ahmed et al. (2010) found that, the sex ratio was 1:1.15 males to females during spawning season.

In the present study, three different broodstock sex ratios: 1:1, 1:2 and 2:1 (male $\delta$ : female () of Solea aegyptiaca were tested. The highest fertilized eggs/ treatment and larvae/ treatment were observed in sex ratio $\left(1 \delta^{\top}: 2 \%\right)$, thereafter, sex ratios $\left(2 \delta^{\lambda}: 1 q\right)$ and $(1 \hat{\delta}: 1 \uparrow)$. While, the highest fertilized eggs/ female, fertilized eggs/ $\mathrm{g}$ female, hatching rate and number of spawning were observed in sex ratio $\left(2 \delta^{\top}: 1\right.$ q $)$. Under the conditions tested in this study, larvae production of Solea aegyptiaca were affected by different broodstock sex ratios and improved at a sex ratio $\left(10^{\lambda}: 2 q\right)$. While, fertilized eggs/ female and/ g female, hatching rate and number of spawning improved at a sex ratio $\left(2 \delta^{\lambda}: 1\right.$ ㅇ $)$. These results agreed with the results in other species; 
Khalfalla et al. (2008) found that, the highest fry production of blue tilapia (Oreochromis aureus) obtained with the sex ratio $\left(10^{\wedge}: 2\right.$ ) from three different broodstock sex ratios (1:1, 1:2 and 1:3 male: female). Also, Nour et al. (2008) evaluated the spawning results of three broad tilapia species, (Oreochromis niloticus, $O$. aureus and $O$. galilaeus) with two sex ratios (1:2 or 1:3 ; male: female ) on the criterias of fry production. The results indicated that $O$. niloticus broad with $\left(1 \delta^{\top}: 2 \bigcirc\right)$ sex ratio produced the highest number of fry. The values of total production fry/ female, number of fry/ female per day, and number of fry/g female showed the same trends. In addition, Mills and Reynolds (2003), found better performance of females stocked at lower sex ratios 1:2 and 1:3 (male: female ) than those stocked at higher 1:4 and 1:5 ( male: female ) sex ratios. Moreover, Salama (1996) found that the highest fry production of Nile tilapia $O$. niloticus obtained with the lower sex ratio (1 male: 2 females). Similarly, Akar (2012) found that the highest fry production of Nile tilapia O. niloticus obtained with the sex ratios 1:2.5 and 1:3 (male: female) from four different broodstock sex ratios (1:1.5, 1:2, 1:2.5 and 1:3 male: female).

On the other hand, Khater (2002) studied the effect of different sex ratio on fry production of both $O$. niloticus and $O$. aueus brood-fish. No significant differences were found between mass spawning of $O$. niloticus and $O$. aureus at the different sex ratio $1: 1,1: 2$ and $1: 3$ in number fry/ $\mathrm{g}$ female body weight. He found that, the sex ratio of 1 male to 3 females is more economical for fry production. Also, Siddiqui and AlHarbi (1997) studied four sex ratios of 1:2, 1:3, 1:4 and 1:5 male to female in hybrid tilapia reared in concrete tanks. They stated that there were no significant differences in seed production between all treatments. As well as, Ridha and Cruz (1998) used male to female sex ratio of 1:3, 1:4 and 1:5; their results showed that seed production was not influenced by sex ratio. Nevertheless, M'Hango and Brummett (1998) found that fry production was significantly higher in 1:1 male to female (111 fry/ female) compared to 1:3 sex ratio (66 fry/ female) for O. shiranus.

In other species, Targonska and Kucharczyk (2012) recorded that, the effectiveness of reproduction increases when there were more males than females in the spawning shoal, with the sex ratio being not lower than 2:1 male to female for Rosy barb (Puntius conchonius) at determination of the number of males in a spawning shoal on the reproduction (1 female and 1, 2, 3, or 4 males). A similar composition of the spawning shoal was recommended in spontaneous reproduction in other species of aquarium fish (Yanong, 1996; Kucharczyk et al., 2008; Spence et al., 2008).

In the present study, larvae production of Solea aegyptiaca were affected by different broodstock sex ratios, and this may be attributed to male fertilization efficiency, as it sometimes happens that more than one female is ready to spawn at the same time, while available males are not sufficient to fertilize the eggs, resulting in unfertilized eggs. Also crowding may have a negative effect (Salama, 1996). Some unfertilized eggs were observed in the sex ratio 2:1 male: female, this may be due to competition between males during spawning activity that caused some eggs to remain unfertilized. In addition, Grant et al. (1995) stated that higher male density led to increase aggression and male-male competition which could reduce the opportunity for female to spawn. This opinion was supported by Akar (2012). Mills and Reynolds (2003) concluded that there was low competition between males and higher spawning frequency with females occurred when fewer males were encountered during spawning activity.

When the sex ratio is equal to $1: 1$ and 1:2, male: female a lower hatching rate happens compared to 2:1, male: female. This may happen for a number of reasons, 
including a low number of spermatozoa produced by one male, which are insufficient to fertilise eggs, which can be attributed to the relatively high fertility of female Solea aegyptiaca. The results of studies of other species suggest that the number of spermatozoa per egg should be as high as over 100,000 (Rurangwa et al., 2004). An insufficient number of spermatozoa results in decrease in the percentage of fertilised eggs, which means a reduced in percentage of growing embryos. Furthermore, an excessively high number of spermatozoa compared to the minimum number increases the embryo survival rate, and sometimes even compensates for the effect of other adverse factors (Rurangwa et al., 1998, 2004; Casselman et al., 2006).

The operational sex ratio (ratio of fertilizable females to sexually active males at a given time) is a principal factor influencing the intensity of sexual selection. The overall adult sex ratio is a key factor affecting sexual competition. If the adult sex ratio is biased, potential rates of reproduction are not sufficient to predict the direction of sexual competition. The sex ratio can also be influenced by the distribution of individuals in time and space, temperature and precopulatory guarding of multiple mates (Debuse et al., 1999).

\section{Effect of stocking density}

Studies on spawning of the sole fish were used stocking density as followed: stocking density $4 \mathrm{fish} / \mathrm{m}^{3}$ equal to $1.04-1.24 \mathrm{Kg} / \mathrm{m}^{3}$ for Solea vulgaris (Assem et al., 2012), stocking density range of $0.8-1 \mathrm{Kg} / \mathrm{m}^{2}$ for Solea solea (Cardinaletti et al., 2009). While Guzman et al. (2009) reported that, the stocking density range of 3-4 $\mathrm{Kg} / \mathrm{m}^{2}$ for Solea senegalensis. Imsland et al. (2003) recorded that, the environmental conditions used for Solea solea and $S$. senegalensis broodfish we find in published studies: moderate densities $\left(0.6-3.0 \mathrm{Kg} / \mathrm{m}^{3}\right.$. Dinis et al. (1999) recorded that, stocking density in the maturation tanks should be $1-1.5 \mathrm{Kg} / \mathrm{m}^{2}$ for $S$. senegalensis. Data of Dinis et al. (2003) indicated that $S$. senegalensis broodstock density might be up to $5 \mathrm{Kg} / \mathrm{m}^{2}$.

In the present study, four different broodstock stocking densities: $0.5,0.75,1$, $1.25 \mathrm{Kg} / \mathrm{m}^{3}$ of Solea aegyptiaca were tested. The highest fertilized eggs/ treatment, fertilized eggs/g female and larvae/ treatment were observed in stocking density $0.75 \mathrm{Kg} / \mathrm{m}^{3}$ followed the other stocking densities, the lowest fertilized eggs/ female and/ $\mathrm{g}$ female were observed in stocking density $1.25 \mathrm{Kg} / \mathrm{m}^{3}$. Under the conditions tested in this study, larvae production of Solea aegyptiaca were affected by different broodstock stocking densities and the best stocking density $0.75 \mathrm{Kg} / \mathrm{m}^{3}$. These results agreed with the results in other species; Shubha and Reddy (2011) who indicated that, increase in stocking density significantly reduced fecundity (eggs/ female) for Oreochromis mossambicus. Also, Tahoun et al. (2008) indicated that increasing broodstock density significantly $(\mathrm{P} \leq 0.05)$ reduced broodstock fecundity (seed per female) for Nile tilpia (Oreochromis niloticus), the lower stocking density had the highest seed/ female, seed/ g female and seed/ day from three different broodstock density (4, 8 and $12 \mathrm{fish} / \mathrm{m}^{2}$ ). As well as, Tsadik and Bar (2007) suggested lower stocking density of 3 broodfish $/ \mathrm{m}^{3}$ to improve seed production of hapa -in- pond tilapia hatcheries. Several researchers studied the effects of different stocking densities on the reproductive performance particularly on Nile tilapia O. niloticus have demonstrated that increasing the level of stocking density significantly $(\mathrm{P} \leq 0.05)$ reduces spawning success and in turn mass production (Little, 1989; Ernst et al. 1991; Ridha and Cruz, 1999; Bhujel, 2000). Bhujel (2000) reported that, an inverse relationship between stocking density and the percentage of spawning females has been found in production hybrids of Tilapia, O. niloticus and O. hornorum, probably due to some chemical or behavioural factors. High stocking density inhibits 
reproduction possibly due to the presence of a substance in Tilapia mucus, which might cause an auto-allergic response.

These results disagreed with the findings in other species of Obi and Shelton (1988) who found that fry production per unit of area $\left(\mathrm{m}^{2}\right)$ in Tilapia, O. hornorum (Trewavas) tended to increase with the increase of broodstock stocking density. Also, Maluwa and Costa-Pierce (1993) reported similar observations for Tilapia, $O$. shiranus. Therefore, the conclusion of the above authors that a high number of seed could be produced at a higher stocking density might be true as long as broodstock density did not exceed the optimum density.

Under the conditions tested in this study, the observed higher fertilized eggs and larvae production at the lower stocking density $\left(0.5\right.$ and $\left.0.75 \mathrm{Kg} / \mathrm{m}^{3}\right)$ compared to other stocking densities indicated more synchronous spawning activity. Increasing the density beyond $0.75 \mathrm{Kg} / \mathrm{m}^{3}$ was not effective to improve larvae production. At high densities, there is a competition for space which increases social interaction and in turn, causes social stress and possibly thereby affecting reproductive efficiency. Present opinion is supported by Shubha and Reddy (2011); Tahoun et al. (2008). Under intensive hatchery system, broodstock are often stocked at high densities in small and confined breeding units such as aquaria and tanks, resulting in aggression and fighting among males and thus, affecting seed production (Behrends et al., 1993). Therefore, the manipulation of broodtock density is one of several technique applied to improve mass production of sole fish seed production than higher densities.

In conclusion, from the results of the present study, it is recommended to conduct artificial spawning of Solea aegyptiaca with sex ratio $\left(1 \delta^{\lambda}: 2\right.$ 을 and stocking density $\left(0.75 \mathrm{Kg} / \mathrm{m}^{3}\right)$.

\section{REFERENCES}

Abdel-Malek, S.A.; Khalil, M.T. and Bishai, H.M. (1993). Aquatic Habitat Diversity. 3. Lake Bardawil. In, Biological Diversity of Egypt. EEAA, 89 pp.

Agulleiro, M.J.; Anguis, V.; Canavate, J.P.; Martinez-Rodriguez, G.; Mylonas, C. C. and Cerda, J. (2006). Induction of spawning of captive-reared Senegal sole (Solea senegalensis) using different administration methods for gonadotropin-releasing hormone agonist. Aquaculture, 257: 511-524.

Ahmed, A.I.; Sharaf, M.M. and Laban, H.A. (2010). Reproduction of the Egyptian sole, Solea aegyptiaca (Actinopterygii: Pleuronectiformes: Soleidae), from Port Said, Egypt, Mediterranean Sea. Acta Ichthyol. Piscat., 40 (2): 161-166.

Akar, A.M. (2012). Effect of sex ratio on reproductive performance of broodstock Nile tilapia (Oreochromis niloticus) in suspended earthen pond hapas. Journal of the Arabian Aquaculture Society., 7 (1): 19-28.

Anguis, V. and Canavate, J.P. (2005). Spawning of captive Senegal sole (Solea senegalensis) under a naturally fluctuating temperature regime. Aquaculture, 243: 133-145.

APHA (1992). Standard methods for the examination of water and waste, $18^{\text {th }} \mathrm{ed}$. American Public Health Association, Washington DC. 1268 pp.

Assem, S.S. (1995). Reprodctive physiology and induced spawning of Solea species. Ph.D thesis, Faculty of Science Alexandria University. 270 pp.

Assem, S.S.; El-Dahhar, A.A.; El-Syed, H.S.; Salama, M.El. and Mourad, M.M. (2012). Induced spawning, embryonic and larval developmental stages of Solea vulgaris in the Mediterranean water. Journal of the Arabian Aquaculture Society, 7 (1): 51-74.

Bambill, G.A.; Oka, M.; Radoni, M.; Lopez, A.V.; Muller, M.I.; Boccanfuso, J.J. and Bianca, F.A. (2006). Broodstock management and induced spawning of Wild black 
argentine flounder Paralichthys orbignyanus under closed recirculated system. Rev. Biol. Mar. Oceanogr., 41: 45-55.

Baynes, S.M. and Howell, B.R. (1996). The influence of egg size and incubation temperature on the condition of Solea solea (L.) larvae at hatching and first feeding. J. Exp. Mar. Biol. Ecol., 199: 59-77.

Bedoui, R. (1995). Rearing of Solea senegalensis (Kaup, 1958) in Tunisia. Cahier Options Mediterrane, 16: 31-39.

Behrends, L.L.; Kingsley, J.B. and Price, A.H. (1993). Hatchery production of blue tilapia Oreochromis aureus (Steindachner) in small hapa nets. Aquaculture and Fisheries Management, 24: 237-243.

Berlinsky, D.L.; King, V.W.; Hodson, R.G. and Sullivan, C.V. (1997). Hormone induced spawning of summer founder Paralichthys dentatus. Journal of the World Aquaculture Society, 28: 79-86.

Bhujel, R.C. (2000). A review of strategies for the management of Nile tilapia (Oreochromis niloticus) broodfish in seed production systems, especially hapa-based systems. Aquaculture, 181: 37-59.

Blanco-Vives, B.; Villamizer, N.; Ramos, J.; Bayarri, M.J.; Chereguini, O. and SanchezVazquez, F.J. (2010). Effect of deily thermo-and photo-cycles of

different light spectrum on the development of Senegal sole (Solea senegalensis) larvae. Aquaculture, 306: 137-145.

Blonk, R.J.W.; Komen, J.; Kamstra, A.; Crooijmans, R.M.A. and van Arendonk, J.A.M. (2009). Levels of inbreeding in group mating captive broodstock populations of Common sole (Solea solea) inferred from parental relatedness and contribution. Aquaculture, 289: 26-31.

Campbell, A.C. (1982). Guide to the flora and fauna of the Mediterranean Sea. Hamlyn. London. New York, Sydney, Toronto., 321pp.

Cardinaletti, G.; Mosconi, G.; Salvatori, R.; Lanari, D.; Tomassoni, D.; Carnevali, O. and Polzonetti-Magni, A.M. (2009). Effect of dietary supplements of mussel and polychaetes on spawning performance of captive sole, Solea solea (Linnaeus, 1758). Animal Reproduction Science, 113: 167-176.

Casselman, S.J.; Schulte-Hostedde, A.I. and Montgomerie, R. (2006). Sperm quality influences male fertilization success in walleye (Sander vitreus). Can. J. Fish. Aquat. Sci., 63: 2119-2125.

Chong, A.S.C.; Ishak, S.D.; Osman, Z. and Hashim, R. (2004). Effect of dietary protein level on the reproductive performance of female swordtails Xiphophorus heleri (Poeciliidae). Aquaculture, 234: 381-392.

Debuse, V.J.; Addison, J.T. and Reynolds, J.D. (1999). The effects of sex ratio on sexual competition in the European lobster. Animal Behaviour, 58: 973-981.

Devauchelle, N.; Alexandre, J.C.; Le-Corre, N. and Letty, Y. (1987). Spawning of sole (Solea solea) in captivity. Aquaculture, 66: 125-147.

Dinis, M.T.; Ribeiro, L.; Soares, F. and Sarasquete, C. (1999). A review on the cultivation potential of Solea senegalensis in Spain and in Portugal. Aquaculture, 176: 27-38.

Dinis, M.T.; Soares, F.; Ribeiro, L.; Engrola, S.; Cacao, P.; Aragao, C.; PousaoFerreira, P. and Conceicao, L.E.C. (2003). Broodstock management and larval rearing of Senegalese sole (Solea senegalensis). In: Book of Abstracts of the World Aquaculture 03, Salvador, Brazil, 19 May-23 May 2003.

Donaldson, E.M. and Hunter, G.A. (1983). Induced final maturation, ovulation and spermiation in cultured fish. In: Hoar, W.S.; Randall, D.J. and Donaldson, E.M. (Editors), Fish Physiology, IXB. Academic Press, London, pp. 351-403.

Eisawy, A. and El-Bolock, A. (1975). Status of aquaculture in the Arab Republic of Egypt. Symposium on aquaculture in Africa, Ghana, 30 Sept. -2 Octob., 1975. 
El-Husseiny, M.M. (2001). Reproductive Biology of Solea sp. in Lake Quarun. MSc. Thesis, Faculty of Science, Ain Shams University, Egypt.

EPA (1983). Methods for chemical analysis of water and wastes. Cincinnati OH, SA: US Environmental Protection Agency 45268: (EPA-600/4-79-020).

Ernst, D.H.; Watanabe, W.O.; Ellingson, L.J.; Wicklund, R.I. and Olla, B.L. (1991). Commercial-scale production of Florida red tilapia seed in low- and brackish-salinity tanks. J. World Aquaculture Soc., 22 (1): 36-44.

Grant, J.W.A.; Bryant, M.J. and Soos, C.E. (1995). Operational sex ratio, mediated by synchrony of female arrival, alters the variance of male mating success in Japanese medaka. Anim. Behav., 49: 367-375.

Guzman, J.M.; Ramos, J.; Mylonas, C.C. and Mananos, E.L. (2009). Spawning performance and plasma levels of GnRHa and sex steroids in cultured female Senegalese sole (Solea senegalensis) treated with different GnRHa-delivery systems. Aquaculture, 291: 200-209.

Hammouda, Y.A.F.; Ibrahim, M.A.R.; Zaki El-Din, M.M.A.; Eid, A.M.S.; Magouz, F.I. and Tahoun, A.M. (2008). Effect of dietary protein levels and sources on reproductive performance and seed quality of Nile tilapia Oreochomis niloicus (L.) broodstock. Abbassa International Journal for Aquaculture, 1(A): 55-78.

Herrera, M.; Hachero, I.; Rosano, M.; Ferrer, J.F.; Marquez, J.M. and Navas, J.I. (2008). First results on spawning, larval rearing and growth of the wedge sole (Dicologoglossa cuneata) in captivity, a candidate species for aquaculture. Aquacult. Int., 16: 69-84.

Ibrahim, M.A.R.; Hammouda, Y.A.F.; Zaki El-Din, M.M.A.; Eid, A.M.S.; Magouz, F.I. and Tahoun, A.M. (2008). Effect of dietary protein levels and sources on growth performance and feed utilization of Nile tilapia Oreochromis niloticus (L.) broodstock. Abbassa International Journal for Aquaculture, 1(B): 251-274.

Imsland, A.K.; Foss, A.; Conceicao, L.E.C.; Dinis, M.T.; Delbare, D.; Schram, E.; Kamstra, A.; Rema, P. and White, P. (2003). A review of the culture potential of Solea solea and S. senegalensis. Reviews in Fish Biology Fisheries, 13: 379-407.

Izquierdo, M.S.; Fernandez-Palacios, H. and Tacon, A.G.J. (2001). Effect of broodstock nutrition on reproductive performance of fish. Aquaculture, 197: 25- 42.

Jimenez, M.P.; Pineiro, C.; Sobrino, I. and Ramos, F. (2001). Studies on age determination and growth pattern of the wedge sole Dicologoglossa cuneata (Moreau, 1881) in the Spanish waters of the Gulf of Cadiz (southwest Iberian Peninsula). Bol. Inst. Esp. Oceanogr., 17(3 and 4): 279-285.

Kariman, A.S. (2009). Some observation on fisheries biology of Tilapia zillii (Gervais, 1884) and Solea vulgaris (Quensel, 1806 in lake Qarun, Egypt. World Journal of Fish and Mar. Sci., 1: 20-28.

Khalfalla, M.M.; Hammouda, Y.A.; Tahoun, A.M. and Abo-State, H.A.M. (2008). Effect of broodstock sex ratio on growth and reproductive performance of blue Tilapia Oreochromis aureus (Steindachner) rered in hapas. $8^{\text {th }}$ International Symposium on Tilapia in Aquaculture, pp. 115-125.

Khater, A.M. (2002). Effect of sex ratios on reproductive performance of Nile tilapia (Oreochromis niloticus) and blue tilapia (Oreochromis aureus) Egypt. J. Agric. Res., 80: 377-386.

Kucharczyk, D.; Targonska, K.; Prusinska, M.; Krejszeff, S.; Kupren, K.; Kujawa, R. and Mmcarz, A. (2008). Reproduction of Buenos Aires tetra (Hemigrammus caudovittatus) under controlled conditions. Pol. J. Natur. Sc., 23(4): 858-865.

Kumagai, A. (1999). Broodstock management and egg collection of Japanese flounder. Hakatajima Station, Annual Report of JASFA: 37-40 (In Japanese). 
Lee, C.S.; Tamaru, C.S. and Kelly, C.D. (1988). The cost and effectiveness of CPH, HCG and LHRH-a on the induced spawning of grey mullet, Mugil cephulus. Aquaculture, 73: 341-347.

Little, D.C. (1989). An evaluation of strategies for production of Nile tilapia (Oreochromis niloticus L.) fry suitable for hormonal treatment. Ph.D. Dissertation, Institute of Aquaculture, University of Stirling, Stirling.

Maluwa, A.O. and Costa-Pierce, B.A. (1993). Effect of broodstock density on Oreochromis shiranus fry production in hapas. Journal of Applied Aquaculture, 2 (2): 63-76.

Mazorra, C.; Bruce, M.; Bell, J.G.; Davie, A.; Alorend, E.; Jordan, N.; Rees, J.; Papanikos, N.; Porter, M. and Bromage, N. (2003). Dietary lipid enhancement of broodstock reproductive and egg and larval quality in Atlantic halibut (Hippoglossus hippoglossus). Aquaculture, 227: 21-33.

Mehanna, S.F. (2007). Stock assessment and management of the Egyption sole (Solea aegyptiaca Chabanaud, 1927, Osteichthyes: Soleidae) in the southeastern Mediterranean, Egypt. Turk. J. Zool., 31: 379-388.

Mehanna, S.F. (2014). Reproductive dynamics of the common sole Solea solea (Linnaeus, 1758) from Bardawil lagoon, North Sinai, Egypt. Conference on International Research on Food Security, Natural Resource Management and Rural Development Organized by the Czech University of Life Sciences Prague. Tropentag, September pp. 17-19.

M'Hango, T. and Brummett, R.E. (1998). Fry production of Shire River tilapia Oreochromis shiranus at two broodstock sex ratios. J. World Aquacult. Soc., 28: 188-192.

Mills, S.C. and Reynolds, J.D. (2003). Operational sex ratio and alternative reproductive behaviours in the European bitterling, Rhodeus sericeus. Behav. Ecol. Sociobiol., 54: 98-104.

Mylonas, C.C. and Zohar, Y. (2001). Use of GnRHa-delivery systems for the control of reproduction in fish. Rev. Fish Biol. Fish., 10: 463-491.

Nour, A.M.; El-Ebiary, S. and Aboelwafa, M. (2008). Spawning effects of broad tilapia species, fed on two dietary protein levels and two sex ratios on fry production. $32^{\text {nd }}$ Annual Larval Fish Conference, Leibniz Institute of Marine Science (IFMGEOMAR) Christian Albrechts University Kiel, Germany, 4-7 August 2008.

Obi, A. and Shelton, W.L. (1988). Effects of broodstock stocking density on fry production in Oreochromis hornorum (Trewavas). J. Aquacult. Tropics, 3:107-110.

Parveen, S. and Mola, H.R.A. (2013). Comparison of physico-chemical parameters and zooplankton species diversity of two perennial ponds in Aligarh, India. J. Env. Biol., 34: 709-716.

Ramos, J. (1986). Larval growth of sole (Solea solea L) at different temperature and photoperids. Biol. Inst. Fsp. Oceanogr., 3 (2): 5-10.

Ridha, M.T. and Cruz, E.M. (1989). Effect of age on the fecundity of the tilapia Oreochromis spilurus . Asian Fish. Sci., 2 (2): 239-247.

Ridha, M.T. and Cruz, E.M. (1998). Observations on the seed production of the tilapia Oreochromis spilurus (Gunther) under different spawning conditions and with different sex ratios. Asian Fish. Sci., 10: 201-210.

Ridha, M.T. and Cruz, E.M. (1999). Effect of different broodstock densities on the reproductive performance of Nile tilapia Oreochromis niloticus (L.), in a recycling system. Aquac. Res., 30: 203-210.

Rosas, F.C.W.; Zuanon, J.A.S. and Carter, S.K. (1999). Feeding ecology of the giant otter Pteronura brasiliensis. Biotropica, 31 (3): 502-506.

Rurangwa, E.; Kime, D.E.; Ollevier, F. and Nash, J.P. (2004). The measurement of sperm motility and factors affecting sperm quality in cultured fish. Aquaculture, 234: 1-28. 
Rurangwa, E.; Roelants, I.; Huyskens, G.; Ebrahimi, M.; Kime, D.E. and Ollevier, F. (1998). The minimum effective spermatozoa: Egg ratio for artificial insemination and the effects of mercury on sperm motility and fertilisation ability in the African catfish Clarias gariepinus. J. Fish Biol., 53: 402-413.

Ruttner-Kolisko, A. (1974). Planktonic rotifers. Biology and Taxonomy. Binnengewasser. Suppl., 26: 146 pp.

Salama, M.E. (1996). Effects of sex ratio and feed quality on mass production of Nile tilapia, Oreochromis niloticus (L.), fry. Aquacult. Res., 27 (8): 581-585.

Salas-Leiton, E.A.; Rodriguez-Rua, A.; Asensio, E.; Infante, C.; Manchado, M.; Fernandez-Diaz, C. and Canavate, J.P. (2012). Effect of salinity on egg hatching, yolk sac absorption and larval rearing of Senegalese sole (Solea senegalensis Kaup 1858). Reviews in Aquaculture, 4: 49-58.

Salivatori, I.L.; Lanzi, M.; Fommei, F. and Angelini, M. (1985). Experiences of artifical reproduction and larval rearing of sole (Solea solea Flower). OEBAUA, VOL. X-2 N.S. 737-744 (in Italy).

Salman, S. (2014). Fisheries characteristics and population dynamics of commercial species of family Soleidae in Bardawil lagoon, North Sinai, Egypt. MSc. Thesis, Suez Canal University.

Shubha, M. and Reddy, S.R. (2011). Effect of stocking density on growth, maturity, fecundity, reproductive behaviour and fry production in the mouth brooding cichlid Oreochromis mossambicus (Peters). African Journal of Biotechnology, 10 (48): 9922-9930.

Siddiqui, A.Q. and Al-Harbi, A.H. (1997). Effects of sex ratio, stocking density and age of hybrid tilapia on seed production in concrete tanks in Saudi Arabia. Aquacult. Int., 5: 207-216.

Smith, S.J.; Watanabe, W.O.; Chan, J.R.; Ernst, D.H.; Wicklund, R.I. and Olla, B.L. (1991). Hatchery production of Florida red tilapia seed in brackishwater tanks: the influence of broodstock age. Aquacult. Fish. Manage., 22 (2): 141-147.

Smith, T.I.J.; McVey, D.C.; Jenkins, W.E.; Denson, M.R.; Heyward, L.D.; Sullivan, C.V. and Berlinsky, D.L. (1999). Broodstock management and spawning of southern flounder, Paralichthys lethostigma. Aquaculture, 176: 87-99.

Spence, R.; Gerlach, G.; Lawrence, C. and Smith, C. (2008). The behavior and ecology of the zebrafish, Danio rerio. Biol. Rev., 83: 13-34.

SPSS (2008). Statistical Package For Social Science (for Windows). Release 17 Copyright (C), SPSS Inc., Chicago, USA.

Swann, L.D. (1997). A fish farmers guide to understanding water quality. Illinois-Indiana Sea Grant Program. AS-503. Purdue University, West Lafayette, Indiana. 8 pp.

Tahoun, A.M.A. (2007). Studies on some factors affecting the production and reproduction of Nile tilapia. Ph.D. Dissertation. Fac. Of Agriculture, kafr El-Sheikh University, Egypt.

Tahoun, A.M.; Ibrahim, M.A.R.; Hammouda, Y.F.; Eid, M.S.; Zaki El-Din, M.M.A. and Magouz, F.I. (2008). Effects of age and stocking density on spawning performance of Nile tilapia, Oreochromis niloticus (L.) broodstock reared in hapas. 8th International Symposium on Tilapia in Aquaculture, pp. 329-343.

Targonska, K. and Kucharczyk, D. (2012). Reproduction of the model fish: Rosy barb (Puntius conchonius), under controlled conditions. Pol. J. Natur. Sc., 27(2): 215-227.

Tsadik, G.G. and Bar, A.N. (2007). Effects of feeding, stocking density and water-flow rate on fecundity, spawning frequency and egg quality of Nile tilapia, Oreochromis niloticus (L.). Aquaculture, 272: 380-388.

Watanabe, W.O. and Carroll, P.M. (2001). Progress in controlled breeding of summer flounder, Paralichthys dentatus, and southern flounder, P. lethostigma. J. Appl. Aquac., 11: 89-111. 
Yanong, R.P.E. (1996). Reproductive management of freshwater ornamental fish. Sem. Avian and Exotic. Pet. Med., 5: 222-235.

Yufera, M.; Parra, G.; Santiago, R. and Carrascosa, M. (1999). Growth, carbon, nitrogen and caloric content of Solea senegalensis (Pisces: Soleidae) from egg fertilization to metamorphosis. Mar. Biol., 134: 43-49.

Zaki, M.L. and Hamza, A.K. (1986). Reproductive biology and induced spawning of Solea solea in Egypt Bull. Inst. Ocean. and Fish. A.R.E., 12: 115-125.

Zaki, M.L. and Hamza, A.K. (1988). Artifical fertilization and development stages of Solea solea. J. Folia Morphological, 36: 229-242.

Zaki, M.I.; Zaher, M.M.; Kamel, S.A. and Abdel-Kawi, S.S. (1998). Rearing of Solea aegyptiaca larval in lake Quarun, Egypt. Ocean Pulse, edited by Tanacredi and Loret. Plenum Press, New York, pp. 127-136.

\section{ARABIC SUMMARY}

$$
\begin{aligned}
& \text { تأثير نسبه الجنسين وكثافة التخزين على التفريخ الأصطناعي لأسماك موسى المصرية. }
\end{aligned}
$$

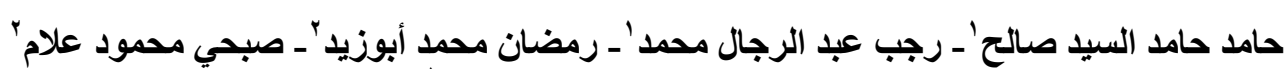

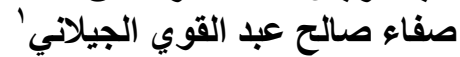

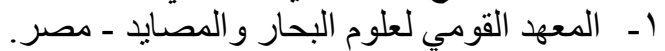

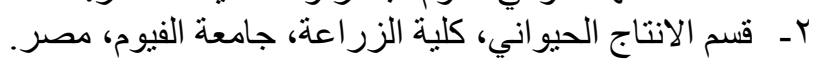

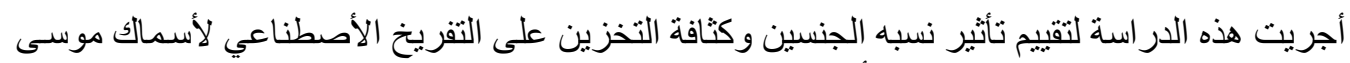

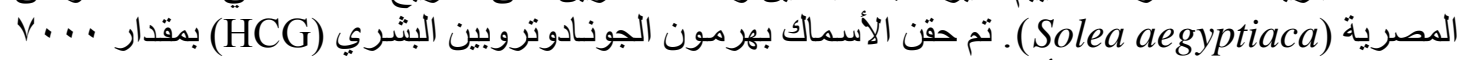

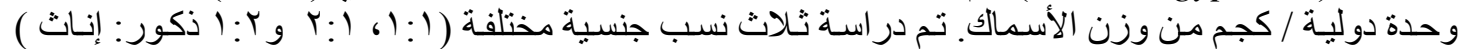

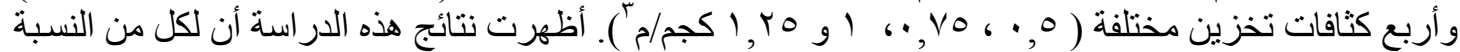

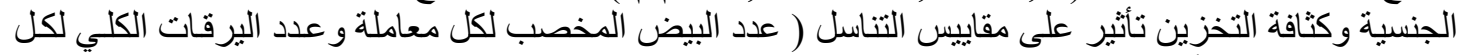

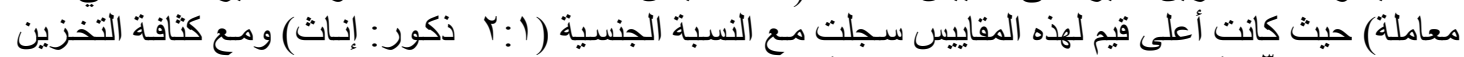

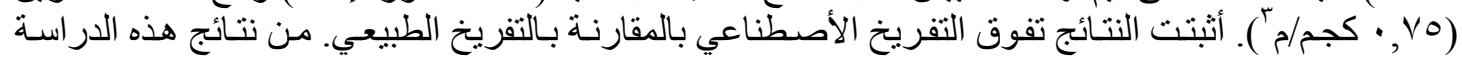

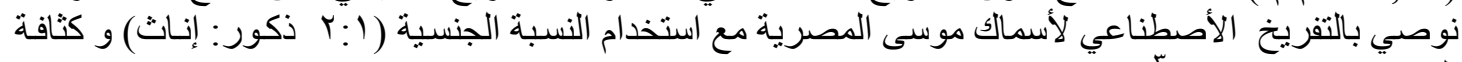

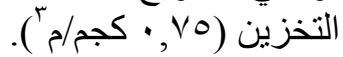

